\title{
Natural Radioactivity Measurements in Vegetables at Al-Diwaniyah Governorate, Iraq and Evaluation of Radiological hazard
}

\author{
Anees A. Al-Hamzawi \\ Department of Physics, College of Education, Al-Qadisiyah University, Qadisiyah-Iraq. \\ Corresponding Author: aneesphys@gmail.com; anees.hassan@qu.edu.iq.
}

\begin{abstract}
The effective technique of $\gamma$-spectroscopy using high purity germanium detector (HPGe) has been applied to determine the specific activity of ${ }^{226} \mathrm{Ra},{ }^{232} \mathrm{Th}$ and ${ }^{40} \mathrm{~K}$ in essential vegetable samples collected from farms of Al-Diwaniyah governorate in the south of Iraq. The specific activity of natural radionuclides was measured in Tomato, Cucumber, Okra, Potato, Radish, Turnip, Spinach, Lettuce, Cauliflower and Onion. The results show that the highest specific activity of ${ }^{226} \mathrm{Ra},{ }^{232} \mathrm{Th}$ and ${ }^{40} \mathrm{~K}$ in potato product was $(11.46,9.12$ and 120.54$) \mathrm{Bq} / \mathrm{kg}$, respectively. The average value of specific activity of radium, thorium and potassium in vegetable samples was (7.67, 5.75 and 98.39) $\mathrm{Bq} / \mathrm{kg}$, respectively. The results of the radiological hazards were compared with the published data and they were found to be within the safety levels. [DOI: 10.22401/JNUS.20.4.09]
\end{abstract}

Keywords: gamma spectroscopy, specific activity, radiological hazard, vegetables.

\section{Introduction}

The terrestrial radionuclides are one of the main categories of Naturally Occurring Radioactive Material (NORM). The terrestrial radionuclides consist of the natural series such as ${ }^{238} \mathrm{U},{ }^{232} \mathrm{Th}$ and non-series such as ${ }^{40} \mathrm{~K}$ which are typically long-lived with a half-life of more than one hundred million years $[1,2]$. Naturally, radionuclides are found in all the environmental elements. They are present in varying amounts in the air, water, vegetables, animals, soil, rocks and the human body itself $[2,3]$. Alpha or beta particles which were emanated from the radionuclides may be taken into the body by absorption or inhalation. This can prompt to an addendum in the internal exposures. Some of these nuclear species are in charge of the emanation of gamma rays which produces the essential source of external exposures to humans [2]. This means that humans are exposed to both internal and external radiation out of these natural sources. Internal exposure occurs via the intake of terrestrial radionuclides through either inhalation or ingestion. The ingestion exposure dose is mostly related to ${ }^{238} \mathrm{U}$ and ${ }^{232} \mathrm{Th}$ decay series as well as ${ }^{40} \mathrm{~K}$ through drinking and eating $[4,5]$. The essential source of common foundation radiation consists of the process of weathering of the earth crust which is the complete mechanism for the redaction of terrestrial radionuclides into the dirt. Plants obtain these radionuclides via roots and leaves, while animals procure radionuclides by means of consumption of these plants. The vegetables and fruits are useful and rich in protein, minerals, vitamins and fibres which human beings are urged to consume in daily diet along with their great benefits to the general health. However, they also consist of fundamental, toxic metals and radionuclides [6]. Natural radioactivity measurements in vegetable samples have been carried out in different countries to establish baseline data from the natural radiation levels [7-10]. The baseline data can be used to assess any changes in the radioactivity background level that occur due to the various activities involved in the radioactive materials fallout in the near future or when compared with future measurements. The measurements also help in the development of the standards, which can be used as future guidelines for the management of these materials. High purity germanium detector (HPGe) is normally used to determine the levels of radionuclides in vegetable samples. This technique appears particularly suitable for quantitative determination of natural radionuclides.

The aim of this study is to determine the natural radioactivity levels and evaluate the radiological hazard in vegetable samples collected from Al-Diwaniyah governorate which is located in the centre-south of Iraq, $(180 \mathrm{~km})$ south of Baghdad as shown in Fig.(1). Al-Diwaniyah governorate has a total 
area of $8,153 \mathrm{~km}^{2}$ and the population was estimated to be $1,320,000$ people. It is situated in a predominantly agricultural region which is extensively irrigated with water provided by the Euphrates River, producing a wide range of vegetables [11].

\section{Materials and Methods}

The present investigation was based on the study of 10 vegetable samples which included tomato, cucumber, okra, potato, radish, turnip, spinach, lettuce, cauliflower and onion were collected from of Al-Diwaniyah farms. About $2-4 \mathrm{~kg}$ of various vegetables, which are sufficient for getting the required amount of ash for gamma spectroscopy, were taken to the laboratory for processing. The vegetable samples were stored in polyethylene bags and labelled properly. The vegetable samples were prepared for measuring the specific activity of the natural radioactivity of ${ }^{226} \mathrm{Ra},{ }^{232} \mathrm{Th}$ and ${ }^{40} \mathrm{~K}$, according to IAEA protocol using high purity germanium detector (HPGe). Using tap water, the vegetable samples were flushed to evacuate the dust and contamination along with the edible portions which were retained for analysis. The samples were stove dried at $110^{\circ} \mathrm{C}$ for $24 \mathrm{~h}$. After that, the stove was utilized to procure vegetable ash and the stove temperature was tardily raised from $150^{\circ} \mathrm{C}$ to the furthest limits of $300^{\circ} \mathrm{C}$. Each of these samples pounded and sieved by utilizing $2 \mathrm{~mm}$ mesh size for homogenization. The samples were conserved in compartments for at least two months to affirm the radioactive balance between ${ }^{226} \mathrm{Ra},{ }^{232} \mathrm{Th}$ and their fugitive offspring [12]. High purity germanium detector system model (Canberra, USA) which has a relative efficiency of $40 \%$ at $(1332 \mathrm{keV})$ for ${ }^{60} \mathrm{Co}$ was used to measure the natural radioactivity in vegetable samples. Spectral data from the detector was analyzed by using computer software (GINE-2000). The detector was surrounded by a lead shielding to reduce the background radiation. The radioactive sources $\left({ }^{22} \mathrm{Na},{ }^{137} \mathrm{Cs},{ }^{60} \mathrm{Co}\right.$ and $\left.{ }^{152} \mathrm{Eu}\right)$ were used to calibrate the system and calculate the efficiency of the detector. Radiometric measurements were performed for $(18000 \mathrm{sec})$ to measure the level of ${ }^{232} \mathrm{Th},{ }^{226} \mathrm{Ra}$ and ${ }^{40} \mathrm{~K}$ present in the vegetables. The activity of ${ }^{232} \mathrm{Th}$ was measured through its daughters ${ }^{212} \mathrm{~Pb}$ and
${ }^{228}$ Ac with energy $583.1 \mathrm{keV}$ and $911.1 \mathrm{keV}$, respectively. While the activity of ${ }^{226} \mathrm{Ra}$ was measured through its daughters ${ }^{214} \mathrm{Bi}$ and ${ }^{214} \mathrm{~Pb}$ with energy $609.3 \mathrm{keV}$ and $351.9 \mathrm{keV}$, respectively. Also the activity of the isotope ${ }^{40} \mathrm{~K}$ was measured at energy $1460.8 \mathrm{keV}$. The specific activity (As) of the radionuclides was calculated from the background subtracted area of prominent gamma-ray energy, via the following relation $[13,14]$.

$$
A_{s}=\frac{C_{n}}{\varepsilon \times I_{\gamma} \times T \times m}
$$

where:

$A_{s}$ is the specific activity in $\mathrm{Bq} / \mathrm{kg}$.

$C_{n}$ is the net count rate under peak per second.

$\mathrm{I}_{\gamma}$ is the gamma-ray emission probability at each energy.

$T$ is the time for counting (sec).

$m$ is the mass of sample $(\mathrm{kg})$.

In order to assess the radiological hazards, the exposure to radiation arising from ${ }^{226} \mathrm{Ra}$, ${ }^{232} \mathrm{Th}$ and ${ }^{40} \mathrm{~K}$ in vegetables can be determined by the following parameters such as radium equivalent activity $\left(\mathrm{Ra}_{\mathrm{eq}}\right)$ in $(\mathrm{Bq} / \mathrm{kg})$ is the most important to assess the radiation hazards and can be expressed using the relation [14].

$R a_{e q}=C_{R a}+1.43 \times C_{T h}+0.07 \times C_{K}$

where $C_{R a}, C_{T h}$ and $C_{K}$ are the specific activity levels $(\mathrm{Bq} / \mathrm{kg})$ of ${ }^{226} \mathrm{Ra},{ }^{232} \mathrm{Th}$ and ${ }^{40} \mathrm{~K}$, respectively.

Also, absorbed dose rate $\left(D_{R}\right)$ in $\left(n G y h^{-1}\right)$ at one meter above the ground surface is determined by the relation [15].

$D_{R}=0.461 \times C_{R a}+0.623 \times C_{T h}+0.041 \times C_{K}$

As well as, hazard index it is referred to the internal hazard index as $\left(\mathrm{H}_{\text {in }}\right)$ and the external hazard index as $\left(\mathrm{H}_{\mathrm{ex}}\right)$. Where $\mathrm{H}_{\mathrm{in}}$ and $\mathrm{H}_{\mathrm{ex}}$ must not exceed the limit of unity for the radiation hazard to be negligible, and estimated via the relations [14].

$H_{\text {in }}=\frac{C_{R a}}{185}+\frac{C_{T h}}{259}+\frac{C_{K}}{4810} \leq 1$
$H_{\text {ex }}=\frac{C_{R a}}{370}+\frac{C_{T h}}{259}+\frac{C_{K}}{4810} \leq 1$ 


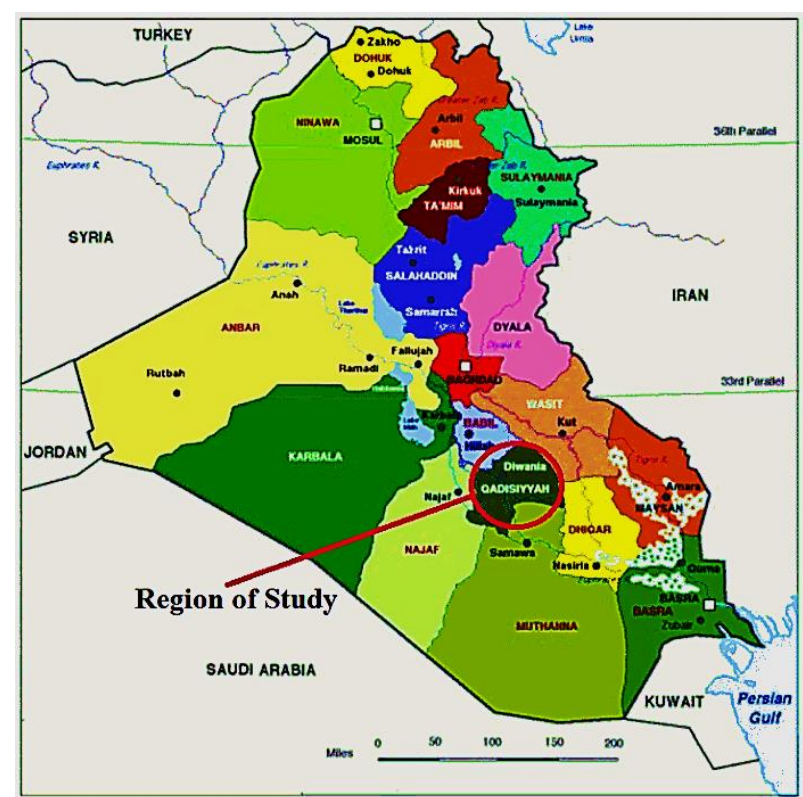

Fig.(1): Map of Iraq showing the location of Al-Diwaniyah governorate.

\section{Results and Discussions}

Table (1) shows the specific activity of the natural radioactivity of ${ }^{226} \mathrm{Ra},{ }^{232} \mathrm{Th}$ and ${ }^{40} \mathrm{~K}$ in selected vegetable samples collected from Al-Diwaniyah governorate. The maximum and minimum value of ${ }^{226} \mathrm{Ra}$ was from $11.46 \mathrm{~Bq} / \mathrm{kg}$ in potato to $4.93 \mathrm{~Bq} / \mathrm{kg}$ in onion with average value of specific activity of ${ }^{226} \mathrm{Ra}$ is $7.67 \mathrm{~Bq} / \mathrm{kg}$. The maximum and minimum value of ${ }^{232} \mathrm{Th}$ was found from $9.12 \mathrm{~Bq} / \mathrm{kg}$ in potato to $3.38 \mathrm{~Bq} / \mathrm{kg}$ which belongs to onion with average value of specific activity of ${ }^{232} \mathrm{Th}$ is $5.75 \mathrm{~Bq} / \mathrm{kg}$. While the maximum and minimum value of ${ }^{40} \mathrm{~K}$ was found $120.54 \mathrm{~Bq} / \mathrm{kg}$ in potato to $77.39 \mathrm{~Bq} / \mathrm{kg}$ in cucumber with average value of specific activity of ${ }^{40} \mathrm{~K}$ is $98.39 \mathrm{~Bq} / \mathrm{kg}$.

From Table (1), it is found that the specific activity of ${ }^{226} \mathrm{Ra},{ }^{232} \mathrm{Th}$ and ${ }^{40} \mathrm{~K}$ in potato was higher than other vegetable samples. The reason behind such results can be attributed to the fact that potato product belongs to the root plants where the transfer of radionuclides from soil to these plants is higher $[2,16]$. Also, the specific activity levels of ${ }^{226} \mathrm{Ra},{ }^{232} \mathrm{Th}$ and ${ }^{40} \mathrm{~K}$ were high in radish and turnip because these vegetables are from category of root vegetables.

\section{Table (1) \\ Specific activity of ${ }^{226} \mathrm{Ra},{ }^{232} \mathrm{Th}$ and ${ }^{40} \mathrm{~K}$ in vegetable samples.}

\begin{tabular}{||c||c||c||c||}
\hline $\begin{array}{c}\text { Vegetable } \\
\text { samples }\end{array}$ & $\begin{array}{c}{ }^{226} \mathbf{R a} \\
(\mathbf{B q} / \mathbf{k g})\end{array}$ & $\begin{array}{c}{ }^{232} \mathbf{T h} \\
(\mathbf{B q} / \mathbf{k g})\end{array}$ & $\begin{array}{c}{ }^{40} \mathbf{K} \\
(\mathbf{B q} / \mathbf{k g})\end{array}$ \\
\hline \hline Tomato & $7.26 \pm 0.31$ & $5.67 \pm 0.26$ & $84.27 \pm 4.48$ \\
\hline Cucumber & $5.82 \pm 0.25$ & $5.17 \pm 0.31$ & $77.39 \pm 5.21$ \\
\hline \hline Okra & $5.61 \pm 0.33$ & $3.75 \pm 0.18$ & $83.54 \pm 3.86$ \\
\hline Potato & $11.46 \pm 0.41$ & $9.12 \pm 0.61$ & $120.54 \pm 4.65$ \\
\hline \hline Radish & $10.22 \pm 0.52$ & $8.17 \pm 0.38$ & $114.23 \pm 5.34$ \\
\hline \hline Turnip & $9.13 \pm 0.30$ & $7.68 \pm 0.47$ & $106.42 \pm 5.87$ \\
\hline \hline Spinach & $6.98 \pm 0.28$ & $4.12 \pm 0.22$ & $104.53 \pm 4.27$ \\
\hline \hline Lettuce & $8.48 \pm 0.42$ & $6.49 \pm 0.26$ & $105.03 \pm 3.75$ \\
\hline Cauliflower & $6.86 \pm 0.27$ & $5.77 \pm 0.31$ & $108.65 \pm 4.12$ \\
\hline \hline Onion & $4.93 \pm 0.17$ & $3.38 \pm 0.19$ & $79.15 \pm 2.93$ \\
\hline \hline Average & $7.67 \pm 0.24$ & $5.75 \pm 0.32$ & $98.39 \pm 4.46$ \\
\hline \hline
\end{tabular}

Table (2) show the values of the radiological hazards such as: Radium equivalent activity, absorbed dose rates and internal and external hazard indices. From Table (2), the highest radium equivalent activity was found in potato sample to be $32.93 \mathrm{~Bq} / \mathrm{kg}$; whereas the lowest was found in onion sample to be $15.31 \mathrm{~Bq} / \mathrm{kg}$. The absorbed dose rate range was found to be 15.91 to $7.63 \mathrm{nGy} / \mathrm{h}$ in potato and onion, respectively. The highest internal and external hazard indices were found in potato sample to be 0.122 and 0.091 respectively; whereas the lowest internal and external hazard indices were found in onion to be 0.056 and 0.042 , respectively.

The results of radium equivalent activity are lower than $370 \mathrm{~Bq} / \mathrm{kg}$ that is safety level reported by [17]. The dose rate is found to be lower than $59 \mathrm{nGy} / \mathrm{h}$ as reported by United Nations Scientific Committee on the Effect of Atomic Radiation Sources (UNSCEAR) [2]. Also, the values of $\mathrm{H}_{\mathrm{in}}$ and $\mathrm{H}_{\mathrm{ex}}$ are lower than unity [2].

Table (3) illustrates a comparison of the results in the present work with those by the previous researchers in different countries. In the current study, the specific activity of ${ }^{226} \mathrm{Ra}$ is higher than the reported values in India, Egypt and Pakistan, and lower than the values reported in Australia, Turkey and Nigeria. Regarding the specific activity of ${ }^{232} \mathrm{Th}$, it is higher than the reported values in India, Australia, Egypt and Pakistan, and lower than the reported values in Turkey and Nigeria. It is 
also found that the specific activity of ${ }^{40} \mathrm{~K}$ is lower than the reported values in India, Egypt, Turkey, Nigeria and Pakistan. When compared to those reported results in Table (3), the high levels of ${ }^{226} \mathrm{Ra}$ and ${ }^{232} \mathrm{Th}$ obtained in this study can be attributed to the use of fertilizers to the soil by the farmers to increase crop yield. Many studies indicated that the fertilizers may be rich in natural radioactive elements and, consequently, their use may enrich these radioactive elements in the plants [18].

Table (2)

Radium equivalent activity $\left(\boldsymbol{R}_{e q}\right)$, absorbed dose rate $\left(D_{R}\right)$ and hazard indices $\left(H_{i n}, H_{e x}\right)$ in vegetable samples.

\begin{tabular}{|c||c||c||c||c||}
\hline $\begin{array}{c}\text { Vegetable } \\
\text { samples }\end{array}$ & $\begin{array}{c}\mathbf{R a}_{\text {eq }} \\
(\mathbf{B q} / \mathbf{k g})\end{array}$ & $\begin{array}{c}\mathbf{D}_{\mathbf{R}} \\
(\mathbf{n G y} / \mathbf{h})\end{array}$ & $\mathbf{H}_{\text {in }}$ & $\mathbf{H}_{\text {ex }}$ \\
\hline \hline Tomato & 21.26 & 10.32 & 0.078 & 0.060 \\
\hline \hline Cucumber & 18.62 & 9.11 & 0.067 & 0.052 \\
\hline \hline Okra & 16.81 & 8.33 & 0.062 & 0.047 \\
\hline \hline Potato & 32.93 & 15.91 & 0.122 & 0.091 \\
\hline Radish & 29.89 & 14.49 & 0.111 & 0.084 \\
\hline \hline Turnip & 27.56 & 13.35 & 0.101 & 0.077 \\
\hline \hline Spinach & 20.18 & 10.07 & 0.076 & 0.056 \\
\hline Lettuce & 25.11 & 12.26 & 0.093 & 0.070 \\
\hline Cauliflower & 22.71 & 11.21 & 0.082 & 0.064 \\
\hline Onion & 15.31 & 7.63 & 0.056 & 0.042 \\
\hline \hline Average & 23.04 & 11.27 & 0.085 & 0.064 \\
\hline
\end{tabular}

Table (3)

Specific activity of natural radioactive elements $(\mathrm{Bg} / \mathrm{kg})$ in vegetable samples for different countries.

\begin{tabular}{|c||c|c||c|c||}
\hline Country & ${ }^{226} \mathbf{R a}$ & ${ }^{232} \mathbf{T h}$ & ${ }^{40} \mathbf{K}$ & References \\
\hline \hline \multirow{2}{*}{ India } & $\begin{array}{c}0.01- \\
1.16\end{array}$ & $\begin{array}{c}0.02- \\
1.26\end{array}$ & $\begin{array}{c}45.9- \\
649\end{array}$ & {$[19]$} \\
\hline \hline Australia & $\begin{array}{c}0.26- \\
134\end{array}$ & $\begin{array}{c}\text { BDL } \\
-0.13\end{array}$ & ----- & {$[20]$} \\
\hline \hline \multirow{2}{*}{ Egypt } & $\begin{array}{c}\text { BDL } \\
-1.5\end{array}$ & $\begin{array}{c}\text { BDL } \\
-4.50\end{array}$ & $\begin{array}{c}235- \\
507\end{array}$ & {$[21]$} \\
\hline \multirow{2}{*}{ Turkey } & $\begin{array}{c}15.9- \\
52.8\end{array}$ & $\begin{array}{c}\text { BDL } \\
-\end{array}$ & $\begin{array}{c}491.6 \\
-\end{array}$ & {$[22]$} \\
\hline \hline \multirow{2}{*}{ Nigeria } & $\begin{array}{c}\text { BDL } \\
-32.1\end{array}$ & $\begin{array}{c}\text { BDL } \\
-9.60\end{array}$ & $\begin{array}{c}8324.5 \\
213\end{array}$ & {$[13]$} \\
\hline \hline \multirow{2}{*}{ Pakistan } & $\begin{array}{c}\text { BDL } \\
-2.41\end{array}$ & $\begin{array}{c}2.37- \\
7.20\end{array}$ & $\begin{array}{c}189.9 \\
-\end{array}$ & {$[23]$} \\
\hline \hline \multirow{2}{*}{ Iraq } & $\begin{array}{c}4.93- \\
11.46\end{array}$ & $\begin{array}{c}3.38- \\
9.12\end{array}$ & $\begin{array}{c}77.39 \\
-\end{array}$ & $\begin{array}{c}\text { Present } \\
\text { work }\end{array}$ \\
\hline \hline
\end{tabular}

BDL: is below detection limit.

\section{Conclusions}

The results obtained show that the specific activity of the natural radioactivity in potato, radish and turnip is higher than tomato, cucumber, okra, spinach, lettuce, cauliflower and onion because these vegetables belong to the root vegetables. The recorded values were compared with the published data and were found to be within the acceptable limits.

\section{Acknowledgements}

Support from department of physics, college of education, university of Al-Qadisiyah is gratefully acknowledged.

\section{References:}

[1] IAEA., "Terminology used in nuclear safety and radiation protection", in IAEA safety glossary, Vienna, 2007.

[2] UNSCEAR., "Effects and risks of ionizing radiation", report to the general Assembly, with scientific annexes, New York, 2000.

[3] IAEA., "Communications on nuclear radiation transport and waste safety", Practical handbook, Vienna, 1999.

[4] Fisenne I., Perry P., Decker K., Keller H., "The daily intake of 234, 235, 238U, 228, 230, 232Th and 226, 228Ra by New York City residents", Health Physics, 53, 357363, 1987.

[5] Shiraishi K., Tagami K., Muramastu Y., Yamamoto M., "Contributions of 18 food categories to intakes of ${ }^{232} \mathrm{Th}$ and ${ }^{238} \mathrm{U}$ in Japan", Health Physics, 78, 28-36. 2000.

[6] Radwan M., Salama A., "Market basket survey for some heavy metals in Egyptian fruits and vegetables", Food and Chemical Toxicology, 44(8), 1273-1278, 2006.

[7] Shafaei M., Saion E., Wood K., Naghavi K., Rezaee K., "Evaluation of ${ }^{40} \mathrm{~K}$ in vegetables collected in Malaysia by the determination of total potassium using neutron activation analysis", Journal of Radioanalytical and Nuclear Chemistry, 288(2), 599-602, 2011.

[8] Shafaei M., Saion E., Wood K., Halimah M., Rezaee K., Mehdipure L., "Evolution of ${ }^{40} \mathrm{~K}$ in fruit collected in Malaysia by the determination of total potassium using neutron activation analysis", Journal of Radioanalytical and Nuclear Chemistry, 284(3), 659-662, 2010. 
[9] Million J., Sartain B., Gonzalez R., Carrier W., "Radium-226 and calcium uptake by crops grown in mixtures of sand and clay tailings from phosphate mining", Journal of Environmental Quality, 23(4), 671-676, 1994.

[10] Misdaq M., Bourzik W., "Evaluation of annual committed effective doses to members of the public in Morocco due to ${ }^{238} \mathrm{U}$ and ${ }^{232} \mathrm{Th}$ in various food materials", Journal of Radiological Protection, 24(4), 391-399, 2004.

[11] IAU., "Diwaniyah Governorate Profile", United Nations, 2015.

[12] Attix H., "Introduction to radiological physics and radiation dosimetry", John Wiley \& Sons, New York, USA, 1986.

[13] Jibiri N., Farai I., Alausa S., "Estimation of annual effective dose due to natural radioactive elements in ingestion of foodstuffs in tin mining area of JosPlateau, Nigeria", Journal of Environmental Radioactivity, 94(1), 31-40, 2007.

[14] Mehra R., Singh S., Singh K., Sonkawade R., ${ }^{6226} \mathrm{Ra},{ }^{232} \mathrm{Th}$ and ${ }^{40} \mathrm{~K}$ analysis in soil samples from some areas of Malwa region, Punjab, India using gamma ray spectrometry", Environmental Monitoring and Assessment, 134(1- 3), 333-342, 2007.

[15] UNSCEAR., "Effects and risks of ionizing radiation", report to the general Assembly, with scientific annexes, New York, 1998.

[16] Aswood M., Jaafar M., Bauk S., "Assessment of radionuclide transfer from soil to vegetables in farms from Cameron Highlands and Penang, (Malaysia) using neutron activation analysis", Applied Physics Research, 5(5), 85- 92, 2013.

[17] OECD., "Exposure to radiation from the natural radioactivity in building materials", Report by the OECD Nuclear Energy Agency, Paris, France, 1979.

[18] Ahmed N., El-Arabi A., "Natural radioactivity in farm soil and phosphate fertilizer and its environmental implications in Qena governorate, Upper Egypt", Journal of Environmental Radioactivity, 84(1), 51-64, 2005.
[19] Ramachandran T., Mishra C., "Measurement of natural radioactivity levels in Indian foodstuffs by gamma spectrometry", International Journal of Radiation Applications and Instrumentation, Part A, Applied Radiation and Isotopes, 40(8), 723-726, 1989.

[20] Ryan B., Martin P., Iles M., "Uraniumseries radionuclides in native fruits and vegetables of northern Australia", Journal of Radioanalytical and Nuclear Chemistry, 264(2), 407-412, 2005.

[21] El-Reefy H., Sharshar T., Zaghloul R., Badran H., "Distribution of gamma-ray emitting radionuclides in the environment of Burullus Lake: I. Soils and vegetations", Journal of Environmental Radioactivity, 87(2), 148-169, 2006.

[22] Bolca M., Saç M., Cokuysal B., Karal T., Ekdal E., "Radioactivity in soils and various foodstuffs from the Gediz River Basin of Turkey", Radiation Measurements, 42(2), 263-270, 2007.

[23] Matiullah M., Ahad A., Faheem M., Nasir T., Rahman S., "Measurement of radioactivity in vegetation of the Bahawalpur Division and Islamabad federal capital territory-Pakistan", Radiation Measurements, 43, S532-S536, 2008. 